\title{
Public Enterprises, Policy Adoption and Planning: Three Welfare Propositions
}

\section{Chiara Del Bo Massimo Florio}

\author{
Working Paper n. 2011-28
}

NOVEMBRE 2011

\section{U n I M I UNIVERSITÃ DEGLI STUDI DI MILANO}

\section{Dipartimento di Scienze Economiche Aziendali e Statistiche}

Via Conservatorio 7 20122 Milano

tel. ++39 0250321501 (21522) - fax ++39 0250321450 (21505) http://www.economia.unimi.it E Mail: dipeco@unimi.it 


\title{
Public enterprises, policy adoption and planning: Three welfare propositions ${ }^{1}$
}

\author{
Chiara Del $\mathrm{Bo}^{2}$, Massimo Florio ${ }^{3}$ \\ Department of Economics, Business and Statistics, Università degli Studi, Milano \\ This version: October 202011
}

\begin{abstract}
Public enterprises are production units of goods or services under government control. In spite of wide privatizations in the last two decades, public provision in this form can be observed in many countries and sectors, particularly in education, health, transport, energy and environment. This paper uses social Cost Benefit Analysis (CBA) theory to explore the rationale for public enterprises. Three welfare propositions arise from CBA theory in a general equilibrium setting:

(1) Under symmetric information and benevolent government, public provision is socially beneficial if: (a) there is a well defined production plan for some goods; (b) optimal policy and socially desirable projects are selected in such a way as to pass a social cost-benefit test at shadow prices; (c) production can never be shut down for some socially desirable goods and optimal procurement is equivalent to public production.

(2) Under not (fully) benevolent government, and asymmetric information: (a) sub-optimal policy adoption leads to inconsistency in project selection; (b) the allocation of property rights will also be distorted, as privatization or government ownership are signals fixed by the government; (c) public provision and public procurement will be no more equivalent, because fo differences in information costs.

(3) If the social planner is not fully benevolent, but cannot profit from policy design: (a) shadow prices are still sufficient statistics for the evaluating changes of the public plan; (b) public enterprises will be welfare superior to privately-owned enterprises (POEs) when the rents of the planner related to public ownership are less than the rents of the private providers under procurement, and shadow prices must be used to compare the outcomes.

The message of the paper points to the overall quality of institutions as a pre-condition for socially desirable public enterprises as this environment provides policy-makers with the correct incentives to design and implement meaningful policies even when public administrators adopt sub-optimal plans. Hence, the building of a sound quality of institutions should be primarily focused on those mechanisms that select policies. Institutions should constrain self-interested policy-makers from disrupting the welfare signals for policy adoption as well as for project appraisal.
\end{abstract}

Keywords: Cost Benefit Analysis; Publicly provided goods; Social welfare JEL codes: D61; H4; I3

\section{Introduction}

Privatization of public services has been widely adopted in the last two decades in many countries, see for example Vickers and Yarrow (1988), Newbery (2000), Florio (2004, 2011), Roland (2008), Megginson and Netter (2001). In spite of this policy trend, many governments, in Europe and elsewhere, still provide services through organizations fully or partly owned by the public sector, particularly in such sectors as education, health, railways, local public transport, electricity and gas, water, sewage, waste collection (for an overview from different perspectives see World Bank, 1994; Bayliss and Fine, 1998; OECD, 2005; CEEP, 2010). In this paper we discuss the welfare rationale of public enterprises, broadly defined as production units under the control of the (central or local) government.

Traditional approaches in economic analysis to public enterprises have mainly viewed them

\footnotetext{
${ }^{1}$ Earlier versions of this paper have been presented at the $\mathrm{X}^{\text {th }}$ Milan European Economy Workshop 2011 and at the XI ${ }^{\text {th }}$ Public Management Research Association (PMRA) Conference, Syracuse (New York State). The authors are grateful to the participants and particularly to Mildred Warner for helpful comments. Financial support from MIUR - PRIN (2008 "The new public enterprise") is gratefully acknowledged. The usual disclaimer applies.

${ }^{2}$ Università degli Studi di Milano (chiara.delbo@unimi.it)
} 
as instruments of government planning (Heal, 1973, or Bös, 1994, for example). Market failures, such as public goods and externalities were often presented as sufficient conditions to justify government provision, even if with some qualifications were advanced, explored by modern public economics (see e.g. Musgrave, 1999, Atkinson and Stiglitz, 1980; or Hindriks and Myles, 2006). Public provision and planning were closely related in this analytical framework, as a social-welfare maximizing government would adopt production plans for socially valuable services and usually delegate the implementation of the plan to government-owned agencies, or through procurement in some cases.

Different strands of theoretical research have however since long questioned the confidence in public provision and planning. Government failures have been seen by many economists as pervasive, and related to ignorance or self-interest of policy makers. The information case against public planning goes back to Von Hayeck (1944) and to other economists in the 'Austrian' tradition (including more recently Littelchild 1986), while the self-interest argument is related to the public choice critique of welfare economics, e.g. Buchanan and Tullock (1962), Peltzman (1980), Mueller (2003). After the collapse of Soviet-type economies and the decline of social democracy in Western Europe (Judt, 2005, 2010), the criticism of public planning and provision has become even more widespread.

Thus, should governments still directly produce goods and own enterprises? While there may be historical or political answers to this question, in this paper we take a normative viewpoint. We discuss some conditions that may justify the role of public enterprises. To do so, we blend together insights from theories of social cost-benefit analysis (in the general equilibrium version by Dréze and Stern, henceforth DS, 1987, 1990), from regulatory economics (Laffont 2000), and political economy (in the meaning of Besley 2006). The presentation will be informal, and rather abstract, but we believe that it offers a useful framework for rethinking the role of public enterprises.

We do not attempt, however, to translate our general ideas into reform recipes, as we just want to set some working hypotheses for future theoretical and applied research. At a later stage, this can also hopefully lead to policy reform implications.

The structure of the paper is the following. The next section presents an informal sketch of the cost-benefit analytical framework, based on the DS setting, which is summarized in the Appendix. The message arising in this context is to restate the view that public projects and policy reforms are socially desirable if they pass a CBA test based on shadow prices. Public enterprises are the agents who implement the government's production plans. Section 3 presents our benchmark model, while section 4 relaxes two implicit hypotheses of this setting: benevolent government and

\footnotetext{
${ }^{3}$ Università degli Studi di Milano (massimo.florio@unimi.it)
} 
symmetric information. There are two possible types of distortions in this context: state capture, in the meaning of Hellman et al (2000) and administrative inefficiency or corruption. Under statecapture both policy adoption and project selection are disrupted, in a precise sense, as shadow prices under distorted policies cannot select welfare improving decisions. Section 5, however, shows that shadow prices are still adequate welfare indicators for the public enterprise even when planning is distorted, provided that policies are not distorted. Section 6 concludes and suggests possible further research.

\section{The Drèze-Stern social cost-benefit setting}

Following Drèze and Stern (1987, 1990), with some adaptations, we can summarize the main ingredients of modern CBA theory as follows. ${ }^{4}$ To simplify, consider a closed economy in which the main agents are: the government, households, private and public firms. Goods can be produced by private or public enterprises. The government aims at maximizing social welfare, which is defined as a suitable aggregation of individual welfare indicators. In order to reach this objective, the government controls the economy through a set of variables such as prices, distortive taxes (optimal lump-sum taxes are not feasible), quantity constraints on private production and consumption and the assignment to households of property rights on private firms, and at the same time matches the excess demands of households by a public production plan.

Given the impossibility of using optimal lump-sum taxes, first-best equilibrium is not feasible, and the government should seek a second-best solution (Atkinson and Stiglitz, 1980 and more recently Lipsey 2007 discuss the origin and developments of the idea of a second-best setting).

Public enterprises are simply firms under the full control of the government, which execute the public production plan and any project that passes a CBA test, as described below. Households maximize utility, a function directly related to consumption of goods, including goods produced by public enterprises. Private firms maximize profits, which are distributed to households, in proportion to their share-holding, or to government (who can be a passive shareholder of 'private' firms, or equivalently can tax a share of profits). Both private firms and households react to information on prices, rations, taxes, and determine their supply and demand accordingly (firms supply goods and demand labour and other production factors; household demand goods and supply labour).

The government is a social planner, perfectly informed and, as said is 'benevolent', i.e. has no other objective than social welfare maximization. Observable prices in this second-best context

\footnotetext{
${ }^{4}$ For a multi-government setting in the context of regional development policies, see Florio (2007) and Florio and Vignetti (2011) for an example of large scale application of CBA in the European Union.
} 
are distorted, except in the trivial case in which the government has a production plan which is nil for any good, sets all signals under his control at a zero level, and private markets are competitive. As observable prices cannot be trusted for taking welfare improving decisions, 'shadow prices' must be computed for the sake of welfare calculations. Shadow prices are opportunity costs of the goods, more precisely defined as the marginal social value of goods around the optimum of the social welfare function adopted by the government, computed by taking into account all the general equilibrium effects related to substitution and complementarity effects across goods. This definition is such that shadow profits reflect the effect of a project on social welfare.

The government does not directly control the economy through the quantity allocation of goods to households and firms (as in a centrally planned economy), but indirectly: by 'indicative planning' to the private sector, and through government production, via the public production plans. The solution of the planning problem of the 'mixed-economy' government (i.e. with private and public provision) can be stated as selecting the level of signals which would lead the economy to the second best welfare position. The marginal social value of a signal, such as a tax or a quantity constraint, is again its marginal contribution to social welfare.

The economy is at its second best when there is no more scope for changing the signal. ${ }^{5}$ Thus a shadow price of a good is a summary statistics of the marginal general equilibrium effects of changing the availability of that good in the economy, given the optimal adoption by the government of the signals that influence the agents' supply and demand. The rule (in fact, mathematically a function in the signals/goods space) that links any change in the public sector production plan to the signals is a 'policy'.

Since the policy function is a central concept in the discussion below, it is important to analyze of its role in the economy, thus providing some intuition to its theoretical foundations. Let us restate the terminology we are going to use. The public sector production plan is the set of quantities or goods to be produced by government agencies, say in one year. A project is a small change in the baseline plan in terms of the quantity to be produced of one specific good. An environment is the set of signals (taxes, prices, property rights etc.) that support the public production plan and, at the same time, the private net demands. In this context a policy is a function which links the public production plan and the signals in such a way that net private demand for goods and public supply of goods balance. In other words, if the government wants to provide health care there should be a residual demand for health care, after part of the demand has been satisfied by private provision, and given a certain set of prices, taxes and subsidies which determine the private demand of health care in the first place. While traditional CBA is a partial equilibrium 
exercise (see e.g. Boardman et al, 2003), in the DS setting all the demand and supply effects should be considered, and are captured by shadow prices. Suppose that a mayor wants to increase local public transport. The local public transport plan is the baseline amount of service to be provided by the municipality. The project is a change in the production plan of the local public sector, for example it is an additional bus line, possibly provided by a municipally owned bus company. This public project can be implemented only by changing something else in the economy of the city: a new bus must be acquired, i.e produced; drivers hired, and perhaps displaced from the private sector; taxes, perhaps on fuel, levied to finance the gap between existing transport fares and the service marginal cost (or the fares must be increased, etc). The changes of the signals will have effects on the capital market, the labour market, which are directly or indirectly related other markets, and possibly on income distribution. Thus, while one may think that the shadow price of the publicly provided bus service is only related to the marginal value of time of passengers, in fact it is also related to the policy that makes this change possible, and to all the resulting associated modifications in the economy. For example, an additional tax on fuel, intended to cover the subsidy for the new bus line, will have an effect on the private automobile market.

In CBA it is customary to say that a public project is approved if it makes profits at shadow prices, i.e. if the social benefits are greater than costs. But under the Dreze and Stern $(1987,1990)$ setting, shadow-pricing goods also involves picking up, at the same time, the right policies to accommodate the public production. In the previous example, the best possible tax change should be selected to finance the public transport project. In this perspective the service provision and the tax decisions are mutually interrelated. Conversely, any potentially beneficial public sector project can be disrupted if the policies that support the public sector plans are wrong. For example, a tax on fuel can be less effective in terms of minimizing the welfare burden for a given tax revenue than a congestion charge. Thus, if the public transport project is associated to an inefficient tax on fuel, the potentially beneficial project will be rejected for the wrong reason. We elaborate below on this view of CBA in order to see its implications for the role of public enterprises. We structure our discussion by some working hypotheses, which are then combined in a more general proposition

The working hypotheses (WH) are conjectures based on earlier theoretical literature, while the propositions link together the WHs in a CBA setting.

\section{The benchmark conceptual model: market failures}

\section{Working Hypothesis 1: No plan, no public enterprise}

Under complete and symmetric information, a necessary (but not sufficient) condition for

\footnotetext{
${ }^{5}$ Mathematically this is the first order condition of the planning problem, equivalent in general to setting to zero the
} 
As mentioned in the previous section, by a public production plan we understand that the net demand of the private sector is met by units under the control of a government layer in such a way that public provision balances demand. In other words, if at a given price and at any other demand determinants' level, there is excess demand, not met by the private sector's production, the latter is matched by public provision. Conversely, one can say that the public production plan is accommodated in the economy through a suitable private net demand. Trivially: for the local bus service to be provided by the public sector, there should be demand for transport that is not yet satisfied by the private sector. Obviously, we need to assume that the government is perfectly informed about demand and production costs and particularly that there is no asymmetry of information between the government and the other agents in the economy. As mentioned, private demand and supply are influenced by certain signals, which are under government control, that can include e.g. producer prices, indirect taxes, direct taxation on production factors, property rights and consumption or production rations. Rationing can be applied on production or on consumption, and can be in the form of 'not less than' or 'no more than'. Given that individual welfare, in the standard framework, is a function of individual consumption, if social welfare is an aggregation of individual welfare, any government should in fact steer the economy in such a way as to balance public provision and net private demand. For the sake of simplicity, let us assume that the public budget must be balanced, and that money finance is impossible. It should be noted that the baseline public production plan is in quantity terms and is not determined by signals (i.e. prices). This is because otherwise the planning problem would have infinite solutions.

For example, if the government wants to produce a certain amount of education or health, the first step involves the solution of the welfare maximization problem, subject to the scarcity constraint (public production should match net private demand). If education or health (the production plan) depends on private sector prices, the maximization problem would have infinite solutions, and the production plan would not be under government's control anymore, and would in the end become part of the private sector. The government's production plan is a prior in the decision process and determines the final economic outcome. ${ }^{6}$

In other words, if the provider behaves as a private firm (a profit maximizer at observed prices), it is not clear why it should be under control (ownership) of the public sector. If however, the government has, for some reason, a plan to offer public transport to disabled people (in-kind subsidy), this is a necessary (but not a sufficient) condition to have a public provider. In fact there 
may be a private provider as well, under a public procurement scheme, an issue we shall discuss below (WH7). Conversely, if there is no such plan, there is certainly no need for a public enterprise.

\section{Working Hypothesis 2: Policy Optimality Condition}

\section{The evaluation of public projects requires that policy selection is second-best optimal in each control area.}

Governments are complex institutions, organized through jurisdictions with their own competencies, and through departments or agencies with well-defined responsibilities. Each of these government layers, or sections, can be seen as a social planner constrained in the use of certain controls. The control area is the feasible set of production plans, projects and supporting available to each unit of government.

Following the DS setting, a policy is a function that associates a production plan to a set of signals. If the local government wants to offer public additional public housing at a discount (compared to market prices) to disadvantaged social groups, a policy is needed to establish $\boldsymbol{e} . g$. the appropriation of a share of added value taxes revenues in that area, in order to finance the project.

If a shadow price is defined as the social opportunity cost of a good, or equivalently as the social welfare change related to the supply (or consumption) of a unit of a good (a small change), and we consider the general equilibrium effects (including redistribution), then in principle the rules used to select the right policy and the right project (i.e. the right change in the public sector production plan) are the same. Suppose that a range of policies are available, e.g. a certain combination of indirect taxes and of tariffs to support an increase in public housing for students or the poor. There is no way to ascertain if a project is socially beneficial if at the same time the related policy is not selected. The problem is trivial if only one policy is available, but what can we say when the municipality has a menu of policy opportunities? In such a circumstance there is no way to compute the social benefit of the project because it depends upon the shadow prices, which in turn depend upon the policies. In plain words you have to compare the welfare gains and losses of beneficiaries of the housing project and of tax-payers, and you cannot do it if the welfare problem is not solved looking at both sides of the welfare change under the two policies. Thus, selecting the optimal indirect tax-tariff combination that supports the project is exactly the same as computing the net benefit of the project given that optimal combination of signals. While this may seem abstract, it has an important implication for public provision (and possibly for public enterprises): the selection of a sub-optimal policy disrupts the logic of the welfare calculation of the benefit of public provision. As we shall see, this fact has some consequences for the design of

\footnotetext{
${ }^{6}$ Alternatively, and equivalently from an analytical perspective, the government may fix the signals that lead the private sector to a certain output and the government's production plan is designed in such a was as to match the excess net private demand.
} 
governance, accountability and performance evaluation, hence the set of incentives for the decision makers.

\section{Working Hypothesis 3: No Exit Condition}

A sufficient condition for public provision is that private provision at market prices is impossible, while there is a socially valuable net private demand for the goods at shadow prices.

A fundamental feature of private production is that there should be freedom of exit for a firm which makes losses at existing prices. Exit is recognized by Hirschman (1970) as perhaps the most important aspect of market mechanisms, as opposed to political mechanisms where 'voice' is the only possibility to change the state of the affairs. Private firms respond to signals set directly or indirectly by the government (national or local). In fact they are defined in such a way. Firms are profit maximizers at observed prices, i.e. at prices that are determined by supply and demand under taxation, rationing, and other uncompetitive features. Differently from the unrealistic world of the Two Fundamental Theorems of Welfare Economics, we live in second-best economies, that are constrained in several ways, as Stiglitz (1994), has convincingly shown, focussing on capital, labour and knowledge markets.

Differently from the private firms, the public enterprise behaves as the agent of a principal, the government, who is here a social welfare maximizer (see WH4 for a departure from this assumption). The fact that, given the set of signals set by the government, there is a demand for some goods that cannot be satisfied by private firms is the widest possible definition of market failure. This definition, is more general than the standard one (see e.g Atkinson and Stiglitz,1980). Private demand in any second best economy is itself determined not just by individual preferences and by technology: it is also determined by signals. These signals, however, are in some cases parameters for the consumer or the firm as influenced by policies. Consumer and production prices in fact can be influenced by the government through taxes, subsidies and rations. Thus 'market' prices are never supporting Walrasian equilibria in the traditional meaning. Individual markets can clear with excess demand and excess supply (one macro-economic version of this setting is Benassy, 2006). ${ }^{7}$

Electricity provision is an example, among many, of the "no exit constraint". While promoters of electricity reforms have invented several ways to try to establish competitive markets, a fundamental deviation from pure competition exists for this specific industry. No government can allow all private firms to shut down their operations if market prices are such that they face losses. California is a recent episode, when the utilities where forced by policy intervention to produce at a loss (Griffin and Puller, 2005). See Helm (2007) for a reappraisal of energy market reforms when 
security of supply is a priority. In transport, Railtrack, the listed owner of tracks in the UK, went near to bankruptcy (Whitehouse, 2003). NATS, the privatized air traffic control in the UK is another example (Majudmar and Ochieng, 2003). In these three cases, governments had to act de facto as providers of last resort (whatever the formal ownership arrangements).

Testing industries with the No Exit Condition is a simple shortcut to see whether the social planner attaches a positive value to operations (at shadow prices) even when private firms would close down ${ }^{8}$.

Let us now summarize the three above mentioned WHs in the following Proposition.

\section{Proposition I}

Under symmetric information and benevolent government, public provision is socially beneficial (a) when there is a well defined public production plan for some goods, (b) when policies are optimal, (such that the public production plan matches net private demand at the least social cost) and projects are selected in such a way as to pass a social cost-benefit test at shadow prices, and (c) when the shut down of the production of some goods is always socially undesirable even when it creates losses at observed prices.

This proposition simply summarizes the implicit message of CBA theory for public provision, and underlines that whatever the legal arrangements, a public firm and a private provider acting under optimal regulation, facing a benevolent government/regulator and under complete and symmetric information are equivalent. See Sappington and Stiglitz (1987) for a related result, and the well known benchmark model of regulation by Laffont and Tirole (1993), henceforth LT.

\section{Government failures and asymmetric information}

We now move to a less abstract and more complex economy, where the world deviates from the previous frame in several ways and we discuss how the previous hypotheses can be adapted to these new features. The aim of this exercise is to inject in the CBA framework some of the intuition of contemporary political economy. A core aspect of the following discussion is the acknowledgment that the public choice critique of welfare economics cannot be ignored or dismissed. It seems obvious that policy makers and administrators are (also) self-interested: how does this simple fact change the previous line of reasoning?

The existence of agency problems under asymmetric information, with related issues of adverse selection and moral hazard, are certainly a feature of complex governmental organizations.

\footnotetext{
${ }^{7}$ For the micro-economics of rationed demand see Neary and Roberts (1980), and for earlier views Tobin and Houttaker (1950).
} 
Would a social CBA framework survive under asymmetric information? These are difficult questions, and we shall again just suggest some working hypotheses that indicate tentative answers.

A core intuition of the political economy literature (Hellman et al 2000) is related to the distinction between 'state capture' (corruption to change the laws) and 'administrative corruption' (corruption to influence the implementation of the existing laws). While this may be a simplification, what we have in mind is the following state of affairs: state capture is related to the selection of policies (and of policy-makers), while administrative corruption is related to the selection of plans (and of administrators in charge of their implementation). To simplify, we assume that the government is made up of two types of agents. The first sets of agents are policy makers, specialized in setting the instruments of the public sector which in this context are embodied into the selection of policies. In other words, it is up to them to take decisions about, for instance, taxation, environmental standards and property rights. The second sets of agents are instead administrators in the public sector, who specialize in the selection of production plans. The policies set the rules of the game. The plans the baseline service level and we assume that project evaluation is then based on simple computation of the net welfare effects of changes in the production plan.

Alesina and Tabellini (2004) observe that accountability and incentive mechanisms for the two types of decision-makers in the public sector are different, and this justifies different analytical approaches. In fact, most of Besley's (2006) discussion on good government is related to political agency issues, while it somewhat neglects the bureaucratic/managerial dimensions which where the concern of previous literature in the tradition of Niskanen (1971) and others. We now turn to the analysis and consider first the existence of inefficient or self interested planning bureaucracy.

\section{Working Hypothesis 4: Not (fully) benevolent public bureaucracy distorts the production plan}

Let us suppose that public planners (or administrators) are not (fully) of the benevolent type, and they have private interests attached to public production plans. This pushes the public production plan away from optimality. However, shadow pricing rules do not change.

While the WH4 may seem obvious, one weak point of public providers in some countries was the decoupling between production units under the control of the public sector and production plans and related objectives. Millward (2010) discusses the rationales for nationalization in Western Europe in the last century in energy and telecoms, and observes a certain shift of objectives over time. Florio (2004) suggests that in the UK the management of nationalized industries as public corporations without firm and clear economic objectives contributed to their privatization. When managers in the administration are not given clear, and verifiable objectives, the scope for

\footnotetext{
${ }^{8}$ In this framework, a private provider which is fully under government's control cannot be behaviourally distinguished from a public enterprise.
} 
inefficiency and corruption increases. A government office in charge of the planning of public production can be prone to special interests. It will adopt a bad public provision plan, ${ }^{9}$ perhaps because it is influenced by some lobbies. For example, it will exaggerate the need of railways, because administrators (we use this word in a broad sense) get side payments from suppliers of inputs to the public railway.

While this fact distorts the 'starting point' of the welfare evaluation, interestingly, it does not change the basic welfare test and the shadow pricing logic of evaluation of a new railway project. This is a direct consequence of the fact that optimality of the plan is desirable, but not necessary to define the shadow prices.

In other words, the provision of one unit of public transport should be offered only if its general equilibrium marginal social cost is less than its marginal social benefit, until for the marginal service unit provided the net benefit is zero. And the shadow price of the service offered, whatever the tariff paid by the disabled person, will be the social opportunity cost of the service. Clearly, a benevolent, fully informed, government office will adopt optimal plans, but for several reasons errors will be done, and in some cases special interests might influence the selection of the plan.

Project decisions are about marginal departures from a status quo. They are not influenced by information on infra-marginal values. By analogy, a profit-maximizing private firm's manager will approve ex-ante the project such that the net present value of marginal revenues equals marginal cost, whatever the mistakes the managers have discovered ex-post in the firm's overall investment plan, or in the decisions taken by other departments. There is nothing better to be done to improve the plan, than to use the opportunity cost of inputs and outputs.

Suppose that for some information constraints the planner does not know with certainty the demand of school minibuses in a rural area. Ex-post the plan can turn out to be sub-optimal, with some excess supply or demand, but ex-ante the expected value of demand, under the Arrow-Lind theorem of public sector risk neutrality (Layard, 1972), is usually appropriate. Moreover, suppose that the local government office is constrained by insufficient transfers from the national government and cannot offer the optimal amount of transport. The plan will be constrained efficient, even if sub-optimal, and it can again be shown that the same cost-benefit rules apply. In this perspective corruption is only one possible source of planning inefficiency, but an inefficient plan does not change the shadow prices to be used for evaluating a new project (if the project is not too large). The only important point is that the plan must be feasible, i.e. it should respect resource constraints and additional constraints, if any.

\footnotetext{
${ }^{9}$ As mentioned, we assume that project selection is instead a transparent computation based on the available information and shadow prices.
} 


\section{Working Hypothesis 5: Distorted policy adoption}

Self-interested or inefficient policy-makers may want to adopt sub-optimal policies. This will undermine welfare enhancing project selection because shadow prices should be based on optimal policies.

Differently from WH4, a non-benevolent dictator or elected policy-maker can distort policy adoption in such a way that sub-optimal policies are selected. This fact is central in the political economy literature. Voters may be unable to discriminate ex-ante, and sometimes ex-post, between good and bad policy-makers, and the latter may enjoy a rent if they disguise themselves as good types. Besley (2006) offers a survey and some extensions of the formal modelling of political agency problems. There are a number of possible sources of failures of government to adopt welfare-maximizing policies, but here we concentrate on three main categories, following Besley (2006). Government failure may pertain both to the actual policy outcome and to the policy selection process. A first notion of government failure is related to Pareto inefficiency, in the sense that a "government fails when policies result in a society being inside its Pareto frontier" (Besley, 2006, p. 49). The outcome of a policy is such that there is a possibility of improving a citizen's well-being without harming another citizen. A second cause of government failure is instead related to distributional issues, which are summarized by social welfare functions. In this context a government failure arises when policies are aimed at favouring political elites or special interests. Finally, in a Wicksellian tradition, a government failure may arise if the outcome of a public policy does not lead to a Pareto improvement with respect to the situation of no government intervention.

These examples are broadly related to different types of government failures, which in turn can be simply defined as situations where government interventions are welfare-dominated by the do-nothing scenario, and are extensively studied in the political economy literature. The difference of effects between government failure of the administration or planning type, and of the "state capture' type is perhaps less noticed. When policy adoption is influenced by low quality policymakers, captured by special interests, or self-interested themselves, or less able to govern in this perspective, shadow pricing becomes inconsistent. Going back to the example of local public transport, suppose that the existing production plan is exogenous, and the administration needs to evaluate a new project. Differently from the setting of WH4, the administration is efficient and benevolent. Informally, suppose that the shadow price of the local public transport service should be computed as the benefit to users of increased service less the social cost of providing the service. The benefit side of the story is often related, in practice, to the earned income of users, as their willingness to pay for the new service will equal, at the margin, the private value of time saved. Some welfare weights will be used to aggregate individual values. The cost side includes, as mentioned above, the value of the inputs used by the project, augmented by the social cost of public 
finance needed to close the gap between tariff revenues and average costs, as in many cities local public transport gets a subsidy. Now, if the elected policy makers adopt a tax change which is not the least socially costly, the shadow price of the project does not lead to a welfare-improving change of the world. In fact, it would always be possible to improve the welfare of the city by not implementing the project, and improving the tax structure. In the administrator's perspective, the existing sub-optimal policy cannot be ignored, because any new expenditure will create welfare losses that are unnecessary. Thus, the benevolent planner must use 'accounting-prices' for project evaluation which are constrained by the wrong policy adoption, and are no more shadow prices as we have defined them in Section 2.

\section{Working Hypothesis 6: Corruption distorts ownership patterns}

\section{Government corruption distorts the decisions of privatization or nationalization in a non linear way.}

This conjecture was suggested by Laffont, 2005, who also provided a simple empirical test of it.

In the framework examined above, a consequence is that control of firms will be suboptimal, but not necessarily in the direction of privatization or nationalization. In fact firms can be nationalized in order to extract rents, or can be privatized for the same reasons. According to Laffont (2005) when policy-makers have a private agenda, the regulators are also at risk of being captured. As ex-post evaluation is costly (see Cella and Florio, 2009), under asymmetric information there is a trade-off. Both benevolent and very corrupted governments may divest public enterprises, for very different reasons. Governments with a 'middle ground' corruption may also have an incentive to privatize, but not necessarily to increase social welfare. Undesirable privatization occurs when the private benefit/cost ratio of the policy-maker exceeds the social value of the divestiture. While this theoretical model has been proposed to elucidate some regulatory issues in developing countries, we think that it offers some helpful insight into the social value of the allocation of property rights by governments. In principle, a divestiture project should be evaluated exactly with the same set of shadow prices as a public investment project. For a discussion of CBA of privatization, see for example Jones et al. (1990), Newbery and Pollitt (1997), Florio (2004). Unfortunately, corruption in policy adoption disrupts the evaluation of privatization projects, exactly for the same argument of WH5. For example, suppose a government with selfinterested policy-makers wants to privatize a public telecommunication corporation. As in Laffont (2005), this can happen for bad or good reasons, according to the weight of the private agenda in the objective function of the government. Moreover, if tax policies are distorted, the social opportunity cost of public funds will be higher than necessary (see Dahlby, 2008 for a discussion). As the (public) telecom company provides precious dividends to the Treasury, clearly the shadow price of money accruing to government should be important in the evaluation, and this parameter enters in 
any evaluation of privatization. Another parameter is the social discount rate, as with privatization the government obtains some proceeds for sale of the assets but foregoes some future income, hence the net present values of future flows must be considered. However, also the social discount rate needs to be calculated assuming that optimal policies are selected, as a sub-optimal tax policy can disturb, for example, the rate of growth of the economy, which enters in the social discount rate (under the social time preference rate approach, see e.g. Evans and Kula, 2011). Thus, state capture has two effects: first, it can directly corrupt the motivation of keeping into or transferring from the public sector certain activities, and -second- indirectly it can disrupt welfare calculation, through the possible inconsistency of shadow prices needed to evaluate the reform, if other policies are distorted.

\section{Working Hypothesis 7: Public procurement}

\section{Under asymmetric information public provision through government-owned enterprises and public} procurement through privately-owned enterprises are no more welfare equivalent.

We turn now directly to public enterprises. The distinction between public "enterprise", "ownership", "provision" and "procurement" from a theoretical point of view might well differ from current usage of the terms (see Meier and O'Toole, 2011, for a recent discussion). It thus seems helpful to clarify some issues, which until now where less prominent in the discussion.

In the DS framework a production unit under the full control of a governmental body is in the public sector, hence is defined as a public enterprise. This has nothing to do with its ownership. A privately owned firm (henceforth POE) that is included in a government production plan and must respect commands from its regulator, $\boldsymbol{e} . \boldsymbol{g}$. on outputs, on prices and purchases of inputs etc., is not different from a state-owned firm that is also part of the production plan. If either GOEs or POEs managers have some freedom in their choices, they can be cost-minimizers or not (Laffont and Tirole, 1993). Let us for a while ignore the latter issue and assume cost minimization for any type of firm.

Conversely, a GOE not fully controlled by the regulatory body is in the private sector, because it will simply respond to signals given it objectives and constraints. One can think, for example, to partly-privatized utilities where the management, after its appointment by the governmental body, behaves independently from the production plan.

One natural way in the DS setting to model this is to say that POEs have possibly quantity constraints on their output that are non-binding for at least one good, while GOEs' output is entirely rationed.

In terms of notation, there are two ways to see a GOE. One is to say that GOEs are nobody's ownership. An alternative the GOE is owned by everybody through its status of citizenship, i.e. it is an endowment, with profits possibly taxed $100 \%$ away. 
When looking at ownership in this way, it is clear why the only difference between a POE and a GOE lies in their inclusion/exclusion in the production plan. Thus, we can understand public procurement as the contract linking a POE to the plan, and under our previous hypothesis of cost minimization, the difference is immaterial if profits are entirely taxed or if there is competitive procurement under symmetric information.

Interestingly, one can think of production units that are public-private partnerships, PPP, not because of ownership arrangements, but because they are partly included in the plan and partly free: one example is a GOE in the health sector that offers both planned assistance and market services for the rest of its capacity (typically extra hours of its personnel).

Having shown that ownership per se is immaterial in defining the public enterprise, we must link the DS and LT frameworks to show that after all a difference may emerge. A well known consequence of information asymmetry is that public ownership potentially emerges as an efficient mechanism to counteract socially costly rents of efficient agent types, as in the incomplete contracts literature. Under public ownership strictu sensu there is no separation between the principal and the agent.

When the regulator/social planner is the owner of the GOE (or appointed by citizensowners), you may assume that because it owns the production unit he is well informed on its technology and can monitor the effort of its management. This may not hold between different layers of government, but here we refer to one single layer, such as a local bus transport company and the transport department of the municipality. This assumption is less realistic when the regulator faces a POE under a service contract. Hence, one way now to differentiate public and private firms is to note that the former is within the information set of the planner, while the latter is not. Again you can conceive intermediate cases, but it is simpler to focus on polar cases.

In this context ownership includes the right to be informed by the shareholder, and is embodied in the right to appoint directors. Thus, a POE, even if included in the public plan under a procurement contract, is now no longer equivalent to a GOE because information is asymmetric, and informative rents can be earned by efficient types in the POE, but in principle not in the GOE. Hence, public procurement and production are no more equivalent in terms of welfare.

Let us now formally summarize WH 4-5-6-7 as follows:

\section{Proposition 2}

Under not (fully) benevolent government, and asymmetric information, while shadow pricing rules do not change if the production plan is further distorted from the optimal one, sub-optimal policy adoption leads to inconsistency in project selection. The allocation of property rights will also be distorted, as privatization or nationalization are signals fixed by the government. Public provision 


\section{and public procurement will be not welfare equivalent, in general.}

The world of Proposition 1 is quite different by the world of Proposition 2. We clearly live in the latter, but we need to understand the former to improve on it.

The independent welfare economist can, in principle, compute her own optimal production plan and pick up second best policies by shadow prices that are consistent with social cost benefit analysis of projects. Public provision will emerge naturally in a second best world from the No Exit Condition.

Conversely, pessimistic public choice economists will tend to look at government as intrinsically inefficient and corrupt and will tend to suggest to give it the least possible role in production (and in regulation). They will use Proposition 2 as support for the market mechanism.

The meaning of Proposition 2, combined with Proposition 1, is however quite different. It suggests that in a world with a specific type of corruption (i.e. corruption in policy adoption) nothing can be said about private or public provision and ownership, because both can be the result of government's capture.

In other words, a (partly) corrupted government that adopts a wrong public provision plan for railways, but picks-up optimal tariff and taxation policies to support it, is much less damaging in welfare terms than a government that adopts an "optimal" production plan but with seriously distorted policies to support it.

When you combine corruption with asymmetric information, a particularly crucial policy, i.e. the allocation of property rights is distorted and either privatization or nationalization can be wrong.

Thus, on a more positive perspective, Proposition 2 suggests that democracy should focus on policy adoption more than on production plans.

\section{Public enterprises and the quality of government}

In what follows we explore some consequences of Proposition 2, when we change some of its ingredients. We regard what follows as a combination of normative and positive perspectives.

\section{Working Hypothesis 8: Shadow prices and institutions}

If the policy-maker is not fully benevolent but cannot profit from policy design, then shadow prices are still sufficient statistics for the value of changes of the public plan.

We do not need to assume that policy-makers are benevolent in order to have an undistorted policy-adoption process. A milder condition is that policy-makers, even if non-benevolent, extract rents from their office in other ways than through law-making. For example, policy-makers can enjoy rents in the form of high remunerations, free flights and accommodation, secretarial staff, and other perks. This is not implying that they will adopt the wrong policies. They may still adopt 
policies which are as near as possible to the optimum, and at the same time enjoy the privileges of their status. The self-interested policy-maker can either extract a rent directly from his position as a law-maker or a member of government in charge of policy decisions, or not. While the latter is probably an unavoidable cost of any political system to a certain extent, the former rent-extracting mechanism is highly dependent upon the nature of the political process, and on constitutional arrangements. For the first mechanism, certain conditions are needed, which are explored by political agency theory. An example of state capture is when a law-maker is able to get the approval of a bill, which is in the special interest of a lobby, and he successfully disguises it as a law, which is in a more general interest. To do so, perhaps, he will need to enter in logrolling activities and form what Besley (2006) describes as Coasian political coalitions. It is well known that such coalitions can be either beneficial or highly damaging in terms of social welfare, hence nothing can be said in principle on the welfare effects of this type of self-interested policy-making. Obviously, autocratic systems are also prone to this type of state capture, but democracies are not entirely protected from opportunism and other behaviours of elected representatives, particularly when in general the information available to the public is limited or distorted. These are indeed very traditional concern of political science.

Early 'public choice' economists have often focussed on rules ('constitutions', 'budgetary rules' etc) which constrain policy-adoption. The welfare effect of such rules, however, cannot be established once and for all. More in general, transparency and freedom of information, duration of tenure, public ethos, etc, can be seen as mechanisms which try to protect policy-making from rentseeking. While, as for Proposition 2, the logic of shadow pricing, i.e. of social cost benefit analysis is disrupted by sub-optimal policies, shadow prices are robust to other forms of self-interest of policy-makers. In other words, social CBA can survive a corrupted law-maker or ministry, provided that there are institutions which protect policy-making, and political rent is distributed in other forms.

\section{Working Hypothesis 9: Relative rents under POE and GOE}

Public enterprises will be welfare superior to privately-owned enterprises when the rents of the planner related to public ownership are less than the rents of the private providers under procurement, and shadow prices must be used to compare the outcomes.

WH9 suggests that under asymmetric information and self interest of some of the players, public procurement and provision are not equivalent anymore in welfare terms. Let us assume that the planner is not entirely benevolent and has a private agenda, hence the SOE is not costminimizing. Is this enough to say that POEs under the plan will be more socially efficient than GOEs? This is not sure in the LT framework, because two inefficiencies need to be compared: the 
socially costly profits of rents earned under public procurement by private owners and the similarly socially costly rents of the not fully benevolent regulator (see Ceriani and Florio, 2011, for a simple example of comparing inefficiencies in different regulatory regimes and Willner, 2010). According to Ceriani and Florio (2011) the consumer's surplus obtained by vertically integrated public ownership is related to any possible inefficiency of the GOE, even if the management is instructed by the government to apply an optimal policy rule, such as pricing at marginal cost. Suppose you have a municipally-owned firm providing water. Assume that the service provided respects the No Exit Condition WH3 and that policies, including the ones necessary to cover the budget deficit of a water firm under natural monopoly, are second-best optimal (i.e. indirect taxes are optimal), or as close to the optimal ones as possible given the constraints faced by the mayor, under WH2. The production plan is less than optimal because the managers of the firm are able to hide some information to the political principal, and do not minimize costs (for example because they do not want to provide their incentive compatible maximum effort to select the best offers by suppliers, to organize the workforce). The political principal observes ex-post this fact, and faces the alternative of privatizing the firm, or starting an auction for the concession of the service à la Demsetz (1967). The information asymmetry and the objectives of the POE are such that the production inefficiency of the municipally owned water service provider must now be compared with the allocative inefficiency of the entrant. Ceriani and Florio (2011) show that price regulation of a privatized provider of network services introduces a distortion of another type, and that even competition is often insufficient to wipe away rents, which need to be compared in the different alternatives. This comparison should be done, in a partial equilibrium setting, by looking at consumer's surpluses, and then looking at rents distributed to other agents. In general equilibrium, the appropriate procedure is to look at shadow prices and calculate the social welfare impact of the reforms, as described in Drèze and Stern (1990), who briefly mention the case of privatization. Thus, if policies are not distorted, the alternative faced by the policy makers, between public provision of water or public procurement, must be compared by welfare calculations based on shadow prices.

We now summarize and conclude by the following:

\section{Proposition 3}

If the social planner is not fully benevolent but cannot profit from policy design, then shadow prices are still sufficient statistics for the value of changes of the public plan; public enterprises will be welfare superior to privately-owned enterprises when the rents of the planner related to public ownership are less than the rents of the private providers under procurement, and shadow prices must be used to compare the outcomes.

In the DS framework, the smallest control area is the fully determined case, when policy is 
exogenous to the (local) layer of government. Thus, the true trade-off between POE and GOE is when there is a range of policies to be selected, different levels of corruption, and different information structures. To be more explicit, in general, one would conjecture that when corruption is low and it is difficult to specify a contract between the government and the agents, a GOE will be the preferred solution. This is because it would be too costly to write a contract contingent to all the states of the world and to the expected efforts and outcomes of the agents in each of them (Sappington and Stigliz, 1987; Schmidt, 1996). The opposite situation is when the government is corrupt but a clear contract can be specified. In this case, the public procurement through a POE will minimize the inefficiency related to the implementation of the contract. This is because, for example, the private firm will pay a lump sum bribe to the corrupt government official but has still an incentive to minimize production costs. ${ }^{10}$

One can think of a family of models that make ownership choice in the implementation of the production plan a function of a small set of parameters for welfare maximization.

\section{Concluding remarks}

This paper contributes to the theory of cost-benefit analysis by integrating some intuitions of contemporary political economy into the framework of applied welfare economics and principalagent theories, as in Laffont (2005). We have first discussed a benchmark conceptual model that develops one specific aspect of the general equilibrium approach to CBA: the relationship between policies and shadow prices when the government is a social welfare maximizer and has full control of public enterprises. The idea that a policy function is needed to properly define shadow prices is due to Drèze and Stern $(1987,1990)$ but has received very limited attention in CBA literature. We, however, suggest that this idea, which explicitly links the evaluation of policies and of goods, potentially establishes an important bridge between welfare economics and political economy.

In the benchmark model, public enterprises, the production units of goods included in a the plan of the public sector, respond to government, and any new project should be evaluated at shadow prices, which in turn are computed at the same time of optimal policies.

The features that make the benchmark model unattractive in practice are the empirical observation of two facts: first that policy-makers are often self-interested principals, and -secondthat they are unable to fully control planners and managers, i.e. their agents.

We have offered some working hypotheses on the implications of these features, and suggested that sub-optimal policy making by self-interested politicians has potentially wide

\footnotetext{
${ }^{10}$ For an early reference to the potential beneficial effect of corruption in developing nations, see Bayley, 1966. For a more recent application, also related to the quality of institutions, see Méon and Weill, 2010.
} 
damaging effects on public investment decisions, privatization, and public procurement. We have also noticed that self- interested administrators can distort planning, but that this is not per se.

The excessively optimistic implications of the benchmark model, and the perhaps excessively pessimistic ones of Proposition 2, are moderated by two closely related statements: that containing political corruption should be a top priority in any economy, while administrative corruption, in principle can be seen as disturbing, but perhaps less devastating.

Besley (2006) offers a theory of the selection of policy makers, which gives us many insights, but does not directly solve the problem we have identified through Proposition 2, while the world of Proposition 1 is just a benchmark. The possible way out is the world of Proposition 3 , where realism about corruption and asymmetric information is combined with reforms that channel rents where they are less damaging.

If the greater threat to social welfare comes usually not from sub-optimal public provision plans, but from wrong and self interested policies, what can we say about mechanisms that contain this class of actions? This is not an easy question, and not necessarily a question that an economist is better equipped than a political scientists to answer. It is, however, in our opinion the core of any rethinking of the potential role of public enterprise after two decades of privatization policies, in those circumstances where, in a well defined welfare meaning, market fails more than government fails.

\section{Appendix: The DS framework}

According to Drèze and Stern, 1987 and 1990, shadow prices ${ }^{11}$ arise as the solution to the optimization of the Social Welfare Function (SWF) in a model with consumers, producers, a social planner and in which the economy is characterized by price rigidities, quantity rationing, trade quotas and exogenous taxes and transfers.

The social planner is defined as the project evaluator, where the project is intended as a change in the net supply of goods by the public sector, characterized by a social welfare function.

The rule that associates a state of the economy with a (public) production plan is defined as a policy. Appropriate signals have to be provided to incentivize people to the desired investment decision or behaviour.

A policy is a function $\Phi($.$) that associates z \rightarrow s$, i.e. it associates a production plan $(z)$ to a vector of signals $(s)$, such that $(s, z)$ meets the side and the scarcity constraints:

\footnotetext{
${ }^{11}$ For a discussion of shadow wages in the DS general equilibrium setting, see Del Bo, Fiorio, Florio, 2011.
} 


$$
\begin{aligned}
& \quad \Phi_{k}(z)=s_{k} \\
& \text { s.t. }(s, z) \text { meets } \\
& \\
& s \in S \\
& \\
& E(s)-z=0
\end{aligned}
$$

where $E(s)$ represents aggregate net demands, $s$ is the vector of signals and $z=\left(\ldots, z_{i}, \ldots\right)$ is the public production plan, i.e. the net supply of the public sector, where $i$ is the index for commodities (including time, space and state of the world). Thus, a project is defined as a marginal change $d z$ (a small project). The scarcity constraint is given by $E(s)-z=0$, while the side constraint is $s \in S$, where $S$ is the opportunity set of the planner.

The social planner maximizes its social welfare function subject to the side and scarcity constraint:

$$
\begin{aligned}
& \quad \max V(s) \\
& \text { s.t. } \\
& s \in(s)-z=0 \text { with } \frac{\partial z_{i}}{\partial s_{n}}=0 .
\end{aligned}
$$

As stated in DS (1987), "the shadow price of a commodity is the total impact on social welfare of a unit increase in the net supply of that commodity from the public sector": $v \equiv \frac{\partial V}{\partial s} \frac{\partial \Phi}{\partial z}$.

The planner has control over signals in order to determine the optimal demand compatible with the exogenous production plan $\mathrm{Z},{ }^{12}$ therefore controlling the environment to which private agents respond to. Formally, the planner maximizes a SWF subject to constraints:

$$
\begin{aligned}
& \max _{s} W\left(V^{1}, \ldots, V^{h}\left(p+t, \bar{x}^{h}, m^{h}\right), \ldots, V^{H}\right) \\
& \text { s.t }\left\{\begin{array}{l}
\sum_{h=1}^{H} x^{h}\left(p+t, \bar{x}^{h}, m^{h}\right)-\sum_{g=1}^{G} y^{g}\left(p, \bar{y}^{g}\right)-Z=0 \\
s \in S
\end{array}\right. \\
& \text { with } E=\sum_{h=1}^{H} x^{h}\left(p+t, \bar{x}^{h}, m^{h}\right)-\sum_{g=1}^{G} y^{g}\left(p, \bar{y}^{g}\right)
\end{aligned}
$$

where $h$ denotes households, $g$ firms, $p$ are producer market prices, $t$ indirect taxes, $y$ and $Z$ are private and public supplies, $x$ is a vector of consumer demands, $v$ are the Lagrange multipliers of the side constraints (which coincide with shadow prices in the model without side constraints), $V$ is the individual utility, barred variables represent quantity constraints or rations and income

\footnotetext{
${ }^{12}$ Which can be either optimally or not optimally chosen.
} 
$m^{h}=r^{h}+\sum_{g} \theta^{g} \pi^{g}\left(p, y^{g}\right)$ is the sum of lump sum transfers and the share of profits $\theta$. The shadow price vector is the gradient of the maximum value function $V^{*}$. The corresponding Lagrangean is:

$$
L=W\left(V^{1}, \ldots, V^{h}\left(p+t, \bar{x}^{h}, m^{h}\right), \ldots, V^{H}\right)-v\left(\sum_{h=1}^{H} x^{h}\left(p+t, \bar{x}^{h}, m^{h}\right)-\sum_{g=1}^{G} y^{g}\left(p, \bar{y}^{g}\right)-Z\right) .
$$

The net effect on social welfare of a small shift of any parameter $\omega$ is indicated by the gradient of the Lagrangean. $Z$ is the net supply of the public sector, which adjusts the net private supply $E(s) . \omega$ is part of $s$, the set of signals through which the public sector influences private agents' economic behavior. Formally, for any parameter $\omega_{k}, \frac{\partial V^{*}}{\partial \omega_{k}}=\frac{\partial L}{\partial \omega_{k}}=\frac{\partial V}{\partial \omega_{k}}-v \frac{\partial E}{\partial \omega_{k}}$ is the marginal social value (MSV). The value of a parameter is optimal form the planner's point of view when its marginal social value is zero.

By considering the MSV of a lump sum transfer to consumer $h\left(r^{h}\right)$, DS define $b^{h}$ and $\beta^{h}$, i.e. the welfare weight, which is the social marginal utility of consumer $h$ 's income, which in turn depends on lump sum transfers.

Formally: $b^{h} \equiv M S V_{r} h=\frac{\partial W}{\partial V^{h}} \frac{\partial V^{h}}{\partial m^{h}}-v \frac{\partial x^{h}}{\partial m^{h}}$ and $\beta^{h} \equiv \frac{\partial W}{\partial V^{h}} \frac{\partial V^{h}}{\partial m^{h}}$.

With these definitions in mind, MSV for each commodity may be computed. By setting the MSV of control variables (such as for example prices) to zero, we can study the shadow pricing rules and optimal policy rules. By studying the MSV of predetermined variables, we can study directions of welfare-improving reforms.

\section{References}

Alesina, A. and Tabellini, G. (2004), "Bureaucrats or Politicians?”, CEPR Discussion Paper no. 4252

Atkinson, A.B. and Stiglitz, J. (1980), Lectures on Public Economics, New York: McGrow Hill

Bayley, D.H. (1966), “The Effects of Corruption in a Developing Nation”, The Western Political Quarterly, 19(4), 719-732

Bayliss, K. and Fine, B. (1998), "Beyond Bureaucrats in Business: a critical review of the World Bank approach to privatization and public sector reform", Journal of International Development, 10(7), 841-855 
Bénassy, J.P. (2006) "Interest rate rules, inflation and the Taylor principle: an analytical exploration", Economic Theory, 27(1) 143-162

Besley T. (2006), Principled Agents? The Political Economy of Good Government, New York, NY: Oxford University Press.

Boardman, A., Greenberg, D., Vining, A. and Weimer D. (2003), Cost-Benefit Analysis: Concepts and Practice, Upper Saddle River, NJ: Pearson Prentice Hall.

Bös, D. (1986), Public enterprise economics: theory and application, Amsterdam and New York: North Holland.

Bös, D. (1994), Pricing and Price Regulation: An Economic Theory for Public Enterprise and Public Utilities. Amsterdam and New York: North Holland

Buchanan, J. M and Tullock, G. (1962) The Calculus of Consent, Logical Foundations of Constitutional Democracy, Ann Arbor, MI: The University of Michigan Press

CEEP (2010), "Public services in the European Union and in the 27 Member States: statistics, organization and regulations", study commissioned in the framework of the "Mapping of the Public Services" project managed by CEEP

Cella, M. and Florio, M. (2009), "Hierarchical contracting in grant decisions: ex-ante and ex-post evaluation in the context of the EU Regional Policy", University of Milano-Bicocca, Department of Economics, Working Papers 171/ 2009.

Ceriani, L and Florio, M. (2011), Consumer's surplus and the reform of network industries: a primer", Journal of Economics, 102(2), 111-122

Dahlby, B. (2008), The Marginal Cost of Public Funds: Theory and Applications, Cambridge, MA: The MIT Press 
Del Bo C., Fiorio C., Florio M. (2011), "Shadow wages in the EU regions”, Fiscal Studies, vol. 32, no. 1 , pp. 109-143.

Demetz, H. (1967), “Towards a theory of property rights”, American Economic Review, 57(2), 347359

Drèze J., Stern N., (1987), "The theory of cost-benefit analysis", in Auerbach A., Feldstein M. (eds), Handbook of public economics, Vol II, Amsterdam and New York: North Holland, 909-989

Drèze J., Stern N. (1990), "Policy reform, shadow prices, and market prices", Journal of Public Economics, 42(1), 1-45.

Evans, D. and Kula, E. (2011), "Social Discount Rates and Welfare Weights for Public Investment Decisions under Budgetary Restrictions: The Case of Cyprus”, Fiscal Studies, 32(1), 73-107

Florio, M. (2004), The great divestiture. Evaluating the welfare impact of the British privatisations 1979-1997,Cambridge, MA: The MIT Press

Florio, M. (2007), "Introduction: multi-government cost-benefit analysis, shadow prices and incentives", in Florio (ed) Cost-benefit analysis and incentives in evaluation. The Structural Funds of the EU, Cheltenham, UK and Northampton, USA: Edward Elgar Publishing, 1-46

Florio, M. and Vignetti S. (2011), "Building a bridge across project evaluation traditions: the contribution of EU Regional Policy”, in Potts D. and Weiss J. (eds) Handbook on Project Analysis and Development, Edward Elgar Publishing

Florio, M. (ed.) (2011), Network Services and Social Welfare. The Experiment that Reshuffled European Utilities, Tenth Milan European Economy Workshop, mimeo

Griffin, J.M and Puller, S. L. (2005), Electricity deregulation: choices and challenges, Chicago, IL: University of Chicago Press

Heal, G. (1973), The theory of economic planning, Amsterdam: North Holland 
Helm, D.R. (2007), "European energy policy: meeting security of supply and climate change challenges", EIB paper 2/2007

Hindriks, J. and G. D. Myles (2006) Intermediate Public Economics, Cambridge, MA: The MIT Press

Hirschman, A. (1970), Exit, Voice, and Loyalty: Responses to Decline in Firms, Organizations, and States, Cambridge, MA: Harvard University Press

Holmberg S., Rothstein B. and Nasiritousi N. (2009), "Quality of Government: What you get”, Annual Review of Political Science, 12, 135-161

Jones L.P, Tandon P. and Vogelsang I. (1990), "Selling Public Enterprises: A Cost/Benefit Methodology, The MIT Press

Judt, T. (2010), Ill Fares the Land, New York, NY: Penguin Press

Judt, T. (2005), Postwar: A History of Europe since 1945, New York, NY: Penguin Press

Laffont J.J., Tirole J. (1993), A Theory of Incentives in Procurement and Regulation, Cambridge, MA: The MIT Press

Laffont, J. J. (2000), Incentives and Political Economy. Oxford, MA: Oxford University Press.

Laffont, J.J. (2005), Regulation and development, Cambridge, UK: Cambridge University Press.

Layard, R. (1972), Cost Benefit Analysis, London, UK: Penguin Books

Lipsey, R. (2007), "Reflections on the general theory of second best at its golden jubilee", International Tax and Public Finance, 14(4), 349-364

Littlechild, S. (1986),The Fallacy of the Mixed Economy: An 'Austrian' Critique of Economic Thinking and Policy, Institute of Economic Affairs, London 
Majumdar, A. and Ochieng, W. (2003), "Part Privatization of United Kingdom's Airspace:

National Air Traffic Services' Experience One Year On", Transportation Research Record: Journal of the Transportation Research Board, 1850, 30-40

Megginson, W. and Netter, J. (2001), "From State to Market: A Survey of Empirical Studies on Privatization", Journal of Economic Literature, 39(2), 321-389

Meier, K.J. and O’Toole L.J.Jr. (2011), “Comparing public and private management: theoretical expectations", Journal of Public Administration Research and Theory, 21(3), i283-i299

Méon, P. and Weill, L. (2010), “ Is Corruption an Efficient Grease?”, World Development, 38 (3), 244-259

Millward, R. (2010), "Public enterprise in the modern western world: an historical analysis", DEAS Working Paper 2010-26

Mueller, D. (2003), Public choice III, Cambridge, UK: Cambridge University Press

Musgrave, R.A. (1999), “The nature of fiscal state: the roots of my thinking”, in J.M. Buchanan and R.A. Musgrave (eds) Public Finance and Public Choice: Two Constraints Visions of the State, Cambridge: CESifo, The MIT Press

Neary, J. P. and Roberts, K. W. S. (1980), "The theory of household behaviour under rationing", European Economic Review, 13(1), 25-42

Newbery, D. and M. Pollitt (1997), “The Restructuring and Privatization of Britain's CEGB - Was it Worth It?", Journal of Industrial Economics, 45(3), 269-303.

Newbery, D.M. (2000), Privatization, Restructuring and Regulation of Network Utilities, (The Walras-Pareto Lectures, 1995), Cambridge, MA: The MIT Press

Niskanen, W. (1971), Bureaucracy \& Representative Government, Chicago, IL: Aldine-Atherton.

OECD (2005), Modernising Government: The Way Forward, Paris: OECD. 
Peltzman, S. (1980), “The Growth of Government”, Journal of Law and Economics, 23(2), 209-87

Roland, G. (2008) (ed), Privatization: Successes and Failures, New York, NY: Columbia University Press

Sappington, D. E.M. and Stiglitz, J. (1987), "Privatization, Information and Incentives", Journal of Policy Analysis and Management (1986-1998), 6(4), 567-579

Schmidt, K. (1996), “The costs and benefits of privatization: an incomplete contracts approach", The Journal of Law and Economics, 12(1), 1-24.

Stiglitz, J. (1994), Whither Socialism?, Cambridge, MA: The MIT Press

Tobin, J. and Houttaker, H.S. (1950), "The effects of rationing on demand elasticities", The Review of Economic Studies, 18(3), 140-153

Vickers J. and G. Yarrow (1988), Privatization: An Economic Analysis, Cambridge, MA: The MIT Press

Von Hayek, F. ([1944]1976) The Road to Serfdom, Chicago, IL: University of Chicago Press

Whitehouse, L. (2003), "Railtrack Is Dead: Long Live Network Rail? Nationalization under the Third Way", Journal of Law and Society, 30(2), 217-235

Willner, J. (2001), “Ownership, efficiency, and political interference”, European Journal of Political Economy, 17(4), 723-748

Willner, J. (2006), "Privatization and liberalization in an industry with network externalities", Economic Letters, 91(2), 197-203

World Bank (1994), "Bureaucrats in Business: The Economics and Politics of Government Ownership Dataset”, World Bank Policy Research Report 